\title{
Determining Ways of Controlling Unruly Students so as to Curb Destruction of School Building in Boarding Public Secondary Schools in Nyanza, Kenya
}

Joshua Odhiambo Ogal: School of Education, Department of Education Management and Curriculum Studies, Mount Kenya University, Kenya.

\begin{abstract}
The research investigated ways of controlling unruly students so as to curb destruction of school building in boarding public secondary schools in Nyanza, Kenya. The concept of discipline should not be associated with pain or fear, but rather it should be viewed as a system of guiding the students to make reasonable decisions. Discipline in school and at home should be that which will produce young people who will be responsible when they become adults. The total number of teachers in affected public secondary schools at the time of the study was 102, 300 students and 50 school principals. A sample size of 150 of the following respondents was suitable for the study, that is 25 deputy principals, 100 students and 25 school principals. Data was collected through questionnaire and interviews. Validity and reliability of the instrument were established through expert opinion and Cronbach's Alpha Coefficient of 0.80 reliability test respectively. Data was analyzed using Coefficient of Determination, Analysis of Variance, frequency counts and percentages. Ways of controlling unruly students so as to curb destruction of school building in boarding public secondary schools were: preventive type of discipline $33.3 \%$, guidance and counseling $52.4 \%$ and application of both preventive and corrective means of discipline scored $47.6 \%$. This study is significant in that it reveals the factors leading to unruly behavior and burning of school premises among boarding public secondary school students in Nyanza. The findings of this study would be useful to the Ministry of Education Science and Technology and the achievement of Kenya Vision 2030 in education.
\end{abstract}

Key words: Ways of controlling, Unruly students, Curb, Destruction and boarding public secondary school.

\section{Introduction}

This chapter discusses the following sub headings: background to the study, Statement of the Problem, Objectives of the Study, Research Questions, Significance of the Study others are Significance of the Study, Assumptions of the Study, Scope of the Study and Definition of Operational Terms.

\subsection{Background to the Study}

Discipline implies responsibility, order and regularity. According to Mbiti (2014) the concept of discipline should not be associated with pain or fear, but rather it should be viewed as a system of guiding the students to make reasonable decisions. He argues that discipline in school and at home should be that which will produce young people who will be responsible when they become adults. They should be able to make their own decisions and accept the consequences of their decisions. They should exercise self-discipline, the kind of persons who do not simply swim with 


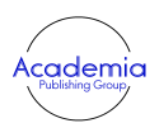

International Journal of Educational Studies

Vol. 3, No.2, pp. 73-87

2020

DOI: $10.53935 / 2641-533 x . v 3 i 2.143$

Funding: This study received no specific

financial support.

Article History:

Received: 13 April 2020

Revised: 23 June 2020

Accepted: 27 July 2020

Published: 21 August 2020

(C) 2020 by the authors; licensee Academic

Publishing Group

174 the current. Every school and every home aims at seeing its products grow into interesting effective people who will make good friends, husbands, wives, parents, neighbors and good citizens. Okumbe (2008) argues that discipline is the action by management to enforce organizational standards. In order to successfully achieve the objectives of a school, all members are required to adhere to various behavior patterns for maximum performance.

Punitive methods: These methods are basically associated with the crisis- management approach, which is reactive in its policy and locates the problems to the student. Tattum (2009) punitive methods rely largely on the infliction of punishment with the aim of deterring the student from committing the crime. Caning out of school, suspension, withdrawal of privileges and expulsion are examples of punitive methods. The principle underlying punitive methods is that when a response is followed by an annoying state of affairs, the connection between this response and stimulus, which preceded it, tends to be weakened. Thorndike (1911); Jones (2009) recommends that the purpose of punishment should be explained, understood and accepted if it is to be effective in enforcing student discipline. According to Jones, students in instinctively expect the punishment for breaking rules will be applied fairly and consistently, otherwise punitive methods may reinforce the occurrences of misbehavior among the students. Docking (1987) agrees with this contention when he notes that although punishment has propensity to deter, to reinforce the importance of school rules and teacher expectations and to prompt culprits to see the error of their ways, unless it is administered sensitively it can alienate, reinforce attentionseeking behavior, encourage avoidance tactics and induce feelings of rejection among the victim students.

Behavior modification methods: Behavior modification methods are basically associated with the interventionist approach, which though reactive in that it responds to problems of misbehavior as they arise it also looks beyond the students for understanding and aims to construct more beneficial relationships helpful to the victim students in observing acceptable codes of conduct. The assumption of this method is that any action that is rewarded will tend to be repeated and learned, whereas actions, which have no favorable consequences to the individual, will cease to be done (Thorndike, 1911) Studies have shown that as reported in Montgomery (1966). A questionnaire was used to gather information from a sample of 396 secondary school students. The researchers found that students generally perceive praise and rewards as appropriate and desirable. Attention praise and nearness produced by teachers help maintain the pro-social behaviors among the students.

According to Mwangi (2018) a horrific early morning fire that killed nine students and left several others injured at Moi Girls High School Nairobi sent shock waves across the country. The pictures of grieving parents and family left many questions unanswered.

Was the fire really started by a student? And in cases where students have been found to be culpable, what goes on in the minds of such young children who will-fully set dormitories aflame and end up killing their schoolmates? What is it that sets of that trigger? In an opinion piece published in this newspaper last year, Dr Evelyne Jepkemei, an educational researcher and leadership expert, disagreed with the notion that arson in school is a purely student rebellion, a spontaneous violent campaign against changing of the school calendar, or a ban on entertainment. She blamed the society, us.

"The current economic woes arising from corruption, robbery, assassinations, smuggling and vandalism are scions of school indiscipline. Court sanctions and orders are universally contravened not only by those who make or interpret the law, but also by those who took the oath to defend the law," wrote the scholar. Jepkemei traced the deviant behavior manifested in schools to situations at home, saying many children report to school with deep-seated insecurities and frustrations. "Some parents are too busy to attend to the emotional needs of their children who then do as they please and keep bad company. The researcher wants to find ways which would help principals control unruly students so as to curb destruction of school building in boarding public secondary schools in Nyanza. 


\subsection{Statement of the Problem}

Discipline implies responsibility, order and regularity. Discipline in school and at home should be that which will produce young people who will be responsible when they become adults. They should be able to make their own decisions and accept the consequences of their decisions. The study was conducted among public boarding secondary school students in Nyanza. Public board Secondary schools in the region have continued to register unruly behavior among students leading to burning of school buildings. According to Collinwood Fire, 1908 erupted on March 4, 1908, killing 172 students, two teachers and one rescuer in one of the deadliest school disasters in United States history. The pictures of grieving parents and family left many questions unanswered. Was the fire really started by a student? And in cases where students have been found to be culpable, what goes on in the minds of such young children who willfully set dormitories aflame and end up killing their schoolmates? Which ways would school principal do to control unruly students, these are some of the issues the research wants addressed in the study and to look for lasting solutions that will bring sanity in boarding public secondary schools within Nyanza region.

\subsection{Objectives of the Study}

The objective of the study was to:

Determine ways of controlling unruly students so as to curb destruction of school building in boarding public secondary schools in Nyanza.

\subsection{Research Questions}

The research questions were as follows:

What are the ways of controlling unruly students so as to curb destruction of school building in boarding public secondary schools in Nyanza?

\subsection{Significance of the Study}

This study is significant in that it reveals the factors leading to unruly behavior and burning of school premises among boarding public secondary school students in Nyanza. The findings of this study would be useful to the Ministry of Education Science and Technology and the achievement of Kenya Vision 2030 in education.

\subsection{Assumptions of the Study}

In this study the researcher made the following assumptions:

There are ways of controlling unruly students so as to curb destruction of school building in boarding public secondary schools in Nyanza

\subsection{Scope of the Study}

The study focused on factors leading to unruly behavior and burning of school premises among boarding public secondary school students in Nyanza. The unruly behavior of students relates to how school management handle students which may lead students showing disrespect to teachers resulting in destruction of school property. The researcher collected data from schools that were affected by arsonists during the time of study.

\subsection{Definition of Operational Terms}

Unruly: uncontrollable, wild, unmanageable, disorderly

Public school: A secondary school supported by public funds through ministry of Education Science and Technology and allocates teachers appointed by TSC.

School Premises: The premises of a property consist of the land and buildings on it

School administrators: Those who are in charge of running the schools i.e. head teachers and their deputies.

\author{
Studies \\ Vol. 3, No.2, pp. 73-87 \\ 2020 \\ DOI: $10.53935 / 2641-533 x . v 3 i 2.143$ \\ financial support. \\ Article History: \\ Received: 13 April 2020 \\ Revised: 23 June 2020 \\ Accepted: 27 July 2020 \\ Published: 21 August 2020 \\ (C) 2020 by the authors; licensee Academic \\ Publishing Group
}




\section{Literature Review}

\subsection{Introduction}

This chapter reviews publications related to factors leading to unruly behavior and burning of school building

\subsection{Ways of Controlling Unruly Students so as to Curb Destruction of School Building in Boarding Public Secondary Schools}

Discipline implies responsibility, order and regularity. According to Mbiti (2014) the concept of discipline should not be associated with pain or fear, but rather it should be viewed as a system of guiding the students to make reasonable decisions. He argues that discipline in school and at home should be that which will produce young people who will be responsible when they become adults. They should be able to make their own decisions and accept the consequences of their decisions. They should exercise self-discipline, the kind of persons who do not simply swim with the current. Every school and every home aims at seeing its products grow into interesting effective people who will make good friends, husbands, wives, parents, neighbors and good citizens. Okumbe (2008) argues that discipline is the action by management to enforce organizational standards. In order to successfully achieve the objectives of a school, all members are required to adhere to various behavior patterns for maximum performance.

Punitive methods: These methods are basically associated with the crisis- management approach, which is reactive in its policy and locates the problems to the student. Tattum (2009) punitive methods rely largely on the infliction of punishment with the aim of deterring the student from committing the crime. Caning out of school, suspension, withdrawal of privileges and expulsion are examples of punitive methods. The principle underlying punitive methods is that when a response is followed by an annoying state of affairs, the connection between this response and stimulus, which preceded it, tends to be weakened. Thorndike (1911); Jones (2009) recommends that the purpose of punishment should be explained, understood and accepted if it is to be effective in enforcing student discipline. According to Jones, students in instinctively expect the punishment for breaking rules will be applied fairly and consistently, otherwise punitive methods may reinforce the occurrences of misbehavior among the students. Docking (1987) agrees with this contention when he notes that although punishment has propensity to deter, to reinforce the importance of school rules and teacher expectations and to prompt culprits to see the error of their ways, unless it is administered sensitively it can alienate, reinforce attentionseeking behavior, encourage avoidance tactics and induce feelings of rejection among the victim students.

Behavior modification methods: Behavior modification methods are basically associated with the interventionist approach, which though reactive in that it responds to problems of misbehavior as they arise it also looks beyond the students for understanding and aims to construct more beneficial relationships helpful to the victim students in observing acceptable codes of conduct. The assumption of this method is that any action that is rewarded will tend to be repeated and learned, whereas actions, which have no favorable consequences to the individual, will cease to be done (Thorndike, 1911) Studies have shown that as reported in Montgomery (1966). A questionnaire was used to gather information from a sample of 396 secondary school students. The researchers found that students generally perceive praise and rewards as appropriate and desirable. Attention praise and nearness produced by teachers help maintain the pro-social behaviors among the students.

Preventive methods: Preventive methods aim at developing structures and processes which are geared towards reducing problems and anticipating crises within the school itself (Duke, 1989; Kuonin, 1970) is of the opinion that a key to preventing discipline problems among the students is the improving of the conditions that lead to their occurrence rather than stressing on rules and punishments. Duke (1989) agrees with this contention when he notes that in improving discipline among students, the emphasis should not be on reactive measures but on policies and strategies, which minimize the risk of disruption in the first place and make it more likely that students will want to behave well. Tattum (2009) suggests the following conditions as being

Vol. 3, No.2, pp. 73-87

2020

This study received no specific

Article History:
Received: 13 April 2020

Revised: 23 June 2020

Accepted: 27 July 2020

(C) 2020 by the authors; licensee Academic Publishing Group 


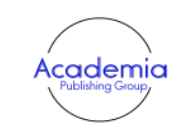

International Journal of Educational Studies

Vol. 3, No.2, pp. 73-87

2020

DOI: $10.53935 / 2641-533 x . v 3 i 2.143$

Funding: This study received no specific

financial support.

Article History

Received: 13 April 2020

Revised: 23 June 2020

Accepted: 27 July 2020

Published: 21 August 2020

(C) 2020 by the authors; licensee Academic

Publishing Group

| 77 necessary minimizing discipline problems in schools; (Teachers and students should be closely involved in the creation as well as review of school rules. Having a more open discussion will bring about a better understanding of their purpose and problems they create for the parties involved.

The rules should be communicated to teachers, parents, students and other involved adults. Students should be made to understand the reasons for implementing the rules. When students are unaware of school rules, they will either fall foul of them unwillingly or test out limits to find out what behavior is acceptable to staff. There should be clarity of expectations; those students and other members of school community understanding, and are aware of what is expected of them and In school there should be a general demonstration of sensitivity and consistency in the administration of school rules. Students need to observe, feel and believe for themselves that their teachers care about them and know something about them as individuals. Said (2016) claims that one of the reasons for conflicts in secondary schools is the object failure of pastoral care in many of them. To Reid, teachers need to be diagnostic of students' need to be diagnostic through the use of pastoral care; Reid (1986) observes that students' needs are likely to be met in time, thus reducing disaffection which can lead to misbehavior among them. In short the literature reviewed above were silent about the ways of Controlling Unruly Students so as to curb Destruction of school Building in Boarding Public Secondary Schools in Nyanza Province a gap this study will address.

\section{Research Methodology}

\subsection{Introduction}

This section outlines the methodology which was used to study factors leading to unruly behavior and burning of school building among boarding public secondary school students in Nyanza. The research design and procedure, sample population, sampling procedure and sample size, validity and reliability of the tools, instrumentation and data collection methods as well as data analysis procedure are described.

\subsection{Research Design}

Descriptive research method was used due to its flexibility in terms of the approach it gives, by means of an in- depth and holistic investigation. It has the aim of collecting rich level descriptions from those participating in the study by permitting them to describe what they experience and feel in their own term. Cohen, Marion, and Morrison (2017) poised that this type of research design is normally useful in investigating a variety of issues and problems. For example, in this study the researcher looks for what is expected of students when their behavior is satisfactory or not. They argue that descriptive research design has an advantage of measuring current practices; it provides required information within a short time and the design is descriptive in its features and can help in describing the nature of what is to be correlated; it can also validate theoretical assumption concerning what is being investigated.

\subsection{Research Location}

The research was done in Nyanza region. The region is comprised of the following Counties: Homa-Bay, Migori, Siaya, Kisumu, Kisii and Nyamira. The region was chosen for the study because of the notable unruly behavior among leaners in almost every midyear leading to burning of school buildings.

\subsection{Study Population}

According to the statistical records from office of the Director of Education, Nyanza Region, the total number of deputy principals in affected public secondary schools at the time of the study was 50, 300 students and 50 school principals. 


\subsection{Sample and Sampling Techniques}

According to (Kothari, 2004); Best and Khan (2006) a sample size of $30 \%$ with reference to the entire population is considered statistically significant for a descriptive research. 150 of the following respondents, was suitable for the study that is 25 deputy principals, 100 students and 25 school principals. Table 3.1 shows the sample frame of the respondents.

\begin{tabular}{|c|c|c|c|c|}
\hline \multirow{2}{*}{ Category of Respondents } & \multirow{2}{*}{$\begin{array}{l}\text { Target } \\
\text { Population } \\
\text { (N) }\end{array}$} & \multirow{2}{*}{$\begin{array}{l}\text { Accessible } \\
\text { Population } \\
\text { (N) }\end{array}$} & \multicolumn{2}{|c|}{ Sample size } \\
\hline & & & $\mathbf{F}$ & $\%$ \\
\hline School principals & 50 & 50 & 25 & 50 \\
\hline Deputy school principals & 50 & 50 & 25 & 50 \\
\hline Students in affected schools & 300 & 300 & 100 & 10 \\
\hline
\end{tabular}

\subsection{Data Collection Instrument}

The researcher used a teacher questionnaire and interview schedule for the school principal. According to Trophim (2016) a questionnaire is a research instrument consisting of a series of questions and other prompts for the purpose of gathering information from respondents. The instrument is the tool the researcher used to collect data from the secondary school teachers, principals and students in Nyanza and later tested to investigate their opinion and recommendations made on the findings from the analysis of the study.

\subsection{Student's Questionnaire on Burning of Schools (SQBS)}

The students ${ }^{\text {e }}$ questionnaire also included a section on their bio data touching on their age, gender and class. Other questions asked had the same view of checking the student responses as pertains to the research questions. In this research (SQBS) was a questionnaire meant to measure students' behavior when they feel aggrieved by the school administration and to analyze factors leading to burning of school building. The questionnaire was structured with closed ended items.

\subsection{Principal and Deputy Principal Questionnaire on Unruly behavior of Students (TOUBS)}

Principal and deputy principal's questionnaire was used to determine ways of controlling unruly students so as to curb destruction of school building in boarding public secondary schools in Nyanza and also to evaluate their role during, before and after students' mayhem in Nyanza region.

\subsection{Principals' Questionnaire and Interview Schedule (PQIS)}

The principals filled a data set of questionnaire and were later interviewed on the details about the challenges faced by school administration in containing unruly students in boarding secondary schools and how they address students' complaints in boarding public secondary school in Nyanza province. The instrument was used during in- depth interview with the principals and the deputies of the sampled schools. The structured interview consisted of already determined content and sequence of questions to make the analysis easier. The open ended questions at the end evoke rich qualitative responses (Orodho, 2004).

\subsection{Validity of Research Instruments}

Validity of an instrument is improved through expert judgment (Gall, Meredith, \& Walter, 2013). As such, the researcher sought assistance of research experts, experienced graduates, lecturers and experienced supervisors in order to help improve content validity of the instruments. In designing an instrument that would yield content valid data, the researcher also identified the domain of indicators which were relevant to factors leading to unruly behavior and burning of school buildings, to ensure that they contained all possible items that would be used in measuring the variables. This process was used to establish the content validity of the instruments.

International Journal of Educational
Studies
Vol. 3 , No.2, pp. $73-87$
2020
DOI: $10.53935 / 2641-533 x . v 3 i 2.143$
Funding: This study received no specific
financial support.
Article History:
Received: 13 April 2020
Revised: 23 June 2020
Accepted: 27 July 2020
Published: 21 August 2020
(C) 2020 by the authors; licensee Academic
Publishing Group
| 78 \\ Academia \\ Vol. 3, No.2, pp. 73-87 \\ DOI: $10.53935 / 2641-533 x . v 3 i 2.143$ \\ financial support. \\ Received: 13 April 202 \\ 178
}




\subsection{Reliability of Research Instruments}

To enhance reliability of the instruments, a pilot study was conducted in two schools in the target population which was excluded in the final study. The reason behind pretesting was to improve reliability of the instruments. The researcher assessed the clarity of the questionnaire items such that the items found to be inadequate or vague were either discarded or modified to improve the quality of the research instrument thus increasing its reliability. Split-half technique of reliability testing was employed, whereby the pilot questionnaires were divided into two equivalent halves and then a correlation coefficient for the two halves computed. Cronbach's Alpha Coefficient of 0.80 confirmed the reliability of the instruments.

\subsection{Data Collection Procedure}

The researcher sought permission from the office of Director of Education, Nyanza region to carry out the research and was issued with a letter introducing him to all sampled schools. He further sought permission from the school principals prior to commencement of data collection. The researcher and two research assistants visited the schools, interviewed the principals and distributed the questionnaire to the teachers and students. The researcher wrote down responses from the interviewees himself, with their consent. Instructions on how to fill the questionnaire was also done and later collected them from the respondents for analysis and discussion.

\subsection{Data Analysis Procedure}

Data was analyzed using, percentages and frequencies. The researcher presented results in tables and employed content analysis in analyzing qualitative data from interview schedules and open ended sections of questionnaires. The researcher wrote down the results in summary form and presented according to emerging sub-themes (Kerlinger, 2013).

\subsection{Ethical Considerations}

The researcher sought informed consent from the respondents, after explaining to them the purpose of the research. Before the questionnaires were administered, the respondents were assured of confidentiality in the treatment of their information and that the responses collected would be used only for the purpose of the research.

\section{Results and Discussion}

\subsection{Introduction}

This chapter presents the findings on the factors leading to unruly behaviour and burning of school buildings among boarding public secondary schools in Nyanza, Kenya. The results of data analysis on Analysis of Factors Leading to Unruly Behaviour and Burning of School building among Boarding Public Secondary School Students in Nyanza, Kenya. Was analysed using SPSS system version 23 software. The results of the analysis which were carried out using descriptive statistic are represented in this chapter according to research objectives.

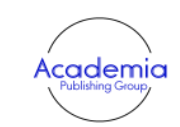

International Journal of Educational Studies

Vol. 3, No.2, pp. 73-87

2020

DOI: $10.53935 / 2641-533 x . v 3 i 2.143$

Funding: This study received no specific

financial support.

Article History:

Received: 13 April 2020

Revised: 23 June 2020

Accepted: 27 July 2020

Published: 21 August 2020

(C) 2020 by the authors; licensee Academic

Publishing Group

179

\subsection{Determine Ways of Controlling Unruly Students So As To Curb Destruction of School Building in Boarding Public Secondary Schools in Nyanza}

This study was guided by the following question: What are the ways of controlling unruly students so as to curb destruction of school building in boarding public secondary schools in Nyanza? In the attempt to understand ways of controlling unruly students so as to curb destruction of school building in public boarding secondary schools in Nyanza province the research had to first look at the category of schools.

\subsection{Category of School}

On the discussion of category of schools, responses of the respondents were as shown in Table 4.1 below. 
Table-4.1. Category of School

\begin{tabular}{|c|c|c|c|c|c|}
\hline \multicolumn{6}{|c|}{ Category of School } \\
\hline & & Frequency & Percent & $\begin{array}{l}\text { Valid } \\
\text { Percent }\end{array}$ & $\begin{array}{l}\text { Cumulative } \\
\text { Percent }\end{array}$ \\
\hline \multirow{5}{*}{ Valid } & Boys Boarding & 4 & 19 & 20 & 20 \\
\hline & Girls Boarding & 5 & 23.8 & 25 & 45 \\
\hline & Mixed Boarding & 3 & 14.3 & 15 & 60 \\
\hline & Mixed Day & 8 & 38.1 & 40 & 100 \\
\hline & Total & 20 & 95.2 & 100 & \\
\hline Missing & System & 1 & 4.8 & & \\
\hline Total & & 21 & 100 & & \\
\hline
\end{tabular}

From Table 4.1 it can be observed that boys boarding public secondary schools were 4 (19\%), girls boarding secondary schools 5 (23.8\%), mixed boarding secondary schools $3(14.3 \%)$ while mixed day secondary schools were $8(38.1 \%)$.

\subsection{Purpose of Discipline}

On the discussion of purpose of discipline, responses respondents were as shown in Table 4.2

Table-4.2. Purpose of Discipline

\begin{tabular}{|c|c|c|c|c|c|}
\hline \multicolumn{6}{|c|}{ Purpose of Discipline } \\
\hline & & Frequency & Percent & $\begin{array}{l}\text { Valid } \\
\text { Percent }\end{array}$ & $\begin{array}{l}\text { Cumulative } \\
\text { Percent }\end{array}$ \\
\hline \multirow{3}{*}{ Valid } & $\begin{array}{l}\text { To punish and therefore reduce the } \\
\text { number of } \\
\text { misbehaving students in School }\end{array}$ & 1 & 4.8 & 4.8 & 4.8 \\
\hline & $\begin{array}{l}\text { To create a conducive school environment } \\
\text { for } \\
\text { effective learning }\end{array}$ & 20 & 95.2 & 95.2 & 100 \\
\hline & Total & 21 & 100 & 100 & \\
\hline
\end{tabular}

From Table 4.2 it can be observed that punish and therefore reduce the number of misbehaving students in schools 1 (4.8\%), creating a conducive school environment for effective learning $20(95.2 \%)$. From the discussion above it is observed that majority proposed that creating conducive school environment for effective learning can boost discipline among learners in public boarding secondary schools in Nyanza province.

\subsection{Type of Discipline most Commonly Applied}

On the discussion of type of discipline most commonly applied in the school, responses of the respondents were as shown on Table 4.3.

From Table 4.3 it can be observed that 7 (33.3\%) support preventive type of discipline to be applied to curb indiscipline and unruly behavior in public secondary schools in Nyanza province, $3(14.3 \%)$ are for corrective measures while $10(47.6 \%)$ say that application of both preventive and corrective means of discipline are appropriate. However, Directorate of Criminal Investigations (DCI) issued a stern warning against all learners in the country, cautioning them against involvement in any form of crime while in school.

Studies

Vol. 3, No.2, pp. 73-87

2020

DOI: $10.53935 / 2641-533 x . v 3 i 2.143$

Funding: This study received no specific

financial support.

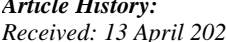

Revised: 23 June 2020

Accepted: 27 July 2020

C 2020 by the authors; licensee Academic

Publishing Group 
Table-4.3. Type of Discipline most commonly applied

\begin{tabular}{|c|c|c|c|c|c|}
\hline \multicolumn{6}{|c|}{ Type of Discipline most commonly applied } \\
\hline & & Frequency & Percent & $\begin{array}{l}\text { Valid } \\
\text { Percent } \\
\end{array}$ & $\begin{array}{l}\text { Cumulative } \\
\text { Percent }\end{array}$ \\
\hline \multirow{4}{*}{ Valid } & Preventive (Encouragement) & 7 & 33.3 & 35 & 35 \\
\hline & $\begin{array}{l}\text { Corrective (Disciplinary } \\
\text { action after infraction) }\end{array}$ & 3 & 14.3 & 15 & 50 \\
\hline & Both in equal proportion & 10 & 47.6 & 50 & 100 \\
\hline & Total & 20 & 95.2 & 100 & \\
\hline Missing & System & 1 & 4.8 & & \\
\hline Total & & 21 & 100 & & \\
\hline
\end{tabular}

\subsection{Most Common Causes of Students Indiscipline}

On the discussion of most common causes of students' indiscipline, responses of the respondents were as shown in Table 4.4 below.

Table-4.4. Most Common Causes of Students Indiscipline

\begin{tabular}{|c|c|c|c|c|c|}
\hline \multicolumn{6}{|c|}{ Most Common Causes of Students Indiscipline } \\
\hline & & Frequency & Percent & $\begin{array}{l}\text { Valid } \\
\text { Percent }\end{array}$ & $\begin{array}{l}\text { Cumulative } \\
\text { Percent }\end{array}$ \\
\hline \multirow{6}{*}{ Valid } & Parental Influence & 1 & 4.8 & 4.8 & 4.8 \\
\hline & Societal Influence & 4 & 19 & 19 & 23.8 \\
\hline & Drug Abuse & 2 & 9.5 & 9.5 & 33.3 \\
\hline & Peer Pressure & 12 & 57.1 & 57.1 & 90.5 \\
\hline & $\begin{array}{l}\text { Political } \\
\text { Interference }\end{array}$ & 2 & 9.5 & 9.5 & 100 \\
\hline & Total & 21 & 100 & 100 & \\
\hline
\end{tabular}

From Table 4.4 above it can be observed that $1(4.8 \%)$ says that parental influence is one of the most common causes of students' indiscipline, social influence $4(19 \%)$, drug abuse $2(9.5 \%)$, peer pressure $12(57.1 \%)$ while political interference $2(9.5 \%)$. From the above discussion it can be noted that peer pressure is the common cause of indiscipline among public boarding secondary schools in Nyanza province. These findings are in line with Mbithi (2012) who argues that the challenges secondary school administration face when dealing with students indiscipline include political interference, parents interference, restriction by laws, lack of support by supervisors, teachers being poor role models, inappropriate knowledge on disciplinary actions and drug abuse by students. He adds that some politicians interfere in the running of secondary schools in their constituencies for political reasons. The members of Parliament will protect head teachers who are under performing for the mere reasons that they are their political point men in the area. Others undermine very hardworking head teachers who may hold political opinions contrary to their own.

\subsection{Most Common Discipline Problems}

On the discussion of most common discipline problems, responses respondents were as shown in Table 4.5 below. 
Table-4.5. Most Common Discipline Problems

\begin{tabular}{lllll}
\hline & Frequency & Percent & $\begin{array}{l}\text { Valid } \\
\text { Percent }\end{array}$ & $\begin{array}{l}\text { Cumulative } \\
\text { Percent }\end{array}$ \\
\hline $\begin{array}{l}\text { Disrespect to teachers } \\
\text { and Principal }\end{array}$ & 1 & 4.8 & 4.8 & 4.8 \\
$\begin{array}{l}\text { Unruly Behaviour e.g. } \\
\text { aggression, Fighting }\end{array}$ & 4 & 19 & 19 & 23.8 \\
$\begin{array}{l}\text { Laziness, Lateness, } \\
\text { absenteeism }\end{array}$ & 10 & 47.6 & 47.6 & 71.4 \\
Valid & 1 & 4.8 & 4.8 & 76.2 \\
$\begin{array}{l}\text { Vulgarity and Sexual } \\
\text { assault }\end{array}$ & 1 & 4.8 & 4.8 & 81 \\
$\begin{array}{l}\text { Drug Abuse } \\
\begin{array}{l}\text { Damage to school } \\
\text { property/theft }\end{array}\end{array}$ & 4 & 19 & 19 & 100 \\
$\quad$ Total & 21 & 100 & 100 & \\
\hline
\end{tabular}

From Table 4.5 above it can be observed that 1 (4.8\%) says that common discipline problem is disrespect to teachers and school principal, 4 (19\%) unruly behavior e.g. laziness, aggression, violence, and lateness, 10 (47.6\%) absenteeism 1 (4.8\%), vulgarity and sexual assault, 1 (4.8\%) drug abuse, and damage to school property/theft $4(19 \%)$. From the discussion above an explained absenteeism is the common discipline problem in public boarding secondary schools in Nyanza province. However, Tattum (2009) suggests the following conditions as being necessary minimizing discipline problems in schools; (Teachers and students should be closely involved in the creation as well as review of school rules. Having a more open discussion will bring about a better understanding of their purpose and problems they create for the parties involved

\subsection{Availability of Guidance and Counselling Staff}

On the discussion of availability of guidance and counselling staff, response of the respondents were as shown in Table 4.6 below

Table-4.6. Availability of guidance and counseling staff

\begin{tabular}{llllll}
\hline \multicolumn{5}{c}{ Availability of guidance and counselling staff } \\
& & Frequency & Percent & Valid Percent & Cumulative Percent \\
\hline \multirow{4}{*}{ Valid } & Yes & 11 & 52.4 & 52.4 & 52.4 \\
& No & 10 & 47.6 & 47.6 & 100 \\
& Total & 21 & 100 & 100 & \\
\hline
\end{tabular}

From Table 4.6 above it can be observed that $11(52.4 \%)$ agree that there is guidance and counselling staff in their school while $10(47.6 \%)$ say no, they do not have a guidance and counsellor in their schools. Presence of guiding and counselling staff can help students alleviate stress that results in organising strikes and destruction of school property. Fiedler and Garcia (2017) pointed out that when stress level was low and the principal was directive (that is, when the principal was willing to tell people what to do) intelligence was more important than experience to the principal's leadership effectiveness. Coincidentally, when in high stress situations, intelligence was of little help because the principal was experienced, too cognitive as a leader, yet stress remains a challenge. According to studies done by Dunham (2016) the extent to which individuals experience stress in any situation depends on the manner in which they assess both the demands and their competence in dealing with them, and their preparedness of the skills necessary for them to handle these demands with a greater sense of competence.

Studies

Vol. 3, No.2, pp. 73-87

financial support.

Article History:

Received: 13 April 2020

Revised: 23 June 2020

Accepted: 27 July 2020

C) 2020 by the authors; licensee Academic Publishing Group 
4.9. Staff Cohesion in Addressing Indiscipline among Students

On the discussion of staff cohesion in addressing indiscipline among students, responses of the respondents were as shown in the Table 4.7 below

Table-4.7. Staff cohesion in addressing indiscipline among students

\begin{tabular}{llllll}
\hline \multicolumn{4}{l}{ Staff cohesion in addressing indiscipline among students } \\
\hline & Frequency & Percent & $\begin{array}{l}\text { Valid } \\
\text { Percent }\end{array}$ & $\begin{array}{l}\text { Cumulative } \\
\text { Percent }\end{array}$ \\
& Firm & 13 & 61.9 & 61.9 & 61.9 \\
\multirow{4}{*}{ Valid } & 2 & 9.5 & 9.5 & 71.4 \\
& Not Very Firm & 6 & 28.6 & 28.6 & 100 \\
& Fair & 21 & 100 & 100 & \\
\cline { 2 - 5 } & Total & &
\end{tabular}

From Table 4.7 above it can be observed that $13(61.9 \%)$ say that staff cohesion in addressing indiscipline among students is firm, 2 (9.5\%) argue that is not very firm while 6 (28.6\%) pointed out that the staff cohesion in addressing indiscipline among students is fair. From the discussion above it can be noted that majority of the respondents conclude that staff members are usually together in addressing indiscipline among the learners. This finding is in line with Ovell (2007) who concludes that discipline in schools is essential for effective learning, good teacher relationship and peer adjustment. A democratic form of discipline leads to a healthy classroom environment that in turn promotes respect for education and a desire for knowledge. According to Okumbe (2001) teachers are supposed to be role models or a shining example at all times. A good high school teacher bears a striking resemblance to a good parent. Among the qualities of a good parent that a high school teacher must exhibit is that of modeling behavior. Unfortunately this is not usually the case and some behaviors exhibited by teachers have led to studentse indiscipline.

\subsection{Frequency of Meetings with Prefects' Body for Consultations}

On the discussion of frequency of meetings with prefects' body for consultations, responses of the respondents were as shown in Table 4.8 below

Table-4.8. Frequency of meetings with prefects' body for consultations

\begin{tabular}{llllll}
\hline & & Frequency & Percent & $\begin{array}{l}\text { Valid } \\
\text { Percent }\end{array}$ & $\begin{array}{l}\text { Cumulative } \\
\text { Percent }\end{array}$ \\
\hline \multirow{4}{*}{ Valid } & As need arises & 4 & 19 & 19 & 19 \\
& On weekly basis & 7 & 33.3 & 33.3 & 52.4 \\
& Monthly & 10 & 47.6 & 47.6 & 100 \\
& Total & 21 & 100 & 100 & \\
\hline
\end{tabular}

From table 4.8 above it can be observed that $4(19.0 \%)$ say that meetings with prefects' body for consultations is as per need arises, 7 (33.3\%) argue that meetings with prefects' body is on weekly basis wile $10(47.6 \%)$ say it is monthly. From the observation above majority posit that meetings with prefects body be done every month so as to control students and also be as close as possible to address their grievances before it's blown out of proportion. However, according to Graffin (1996) teachers are meant to have absolute powers over students, visible in methods of reward or punishment used by the teacher because of student indiscipline. In Kenya prefects assist in maintaining discipline, $\mathrm{He}$ adds that there is a great need to select, train and equip prefects with skills to manage themselves, fellow students, time, school duties and their studies. When responsibilities are delegated to prefects without proper guidance they get confused, stressed and more often than not destroyed. Expecting prefects to tame hostile adolescent students when they are going through the same internal turmoil is asking a bit too much from

Studies

Vol. 3, No.2, pp. 73-87

2020

Article History:
Received: 13 April 2020

Revised: 23 June 2020

Accepted: 27 July 2020

(c) 2020 by the authors; licensee Academic Publishing Group 
students. Special attention should be dedicated to guidance on how to harmonize prefects' roles as students as well as student leaders.

\subsection{Methods/Measures Commonly Applied in Enhancing Discipline in School}

On the discussion of methods/measures commonly applied in enhancing discipline in school, responses of the respondents were as shown in Table 4.9 below.

Table-4.9. Methods/Measures commonly applied in enhancing discipline in school

\begin{tabular}{|c|c|c|c|c|c|}
\hline \multicolumn{6}{|c|}{ Methods/Measures commonly applied in enhancing discipline in school } \\
\hline & & Frequency & Percent & $\begin{array}{l}\text { Valid } \\
\text { Percent }\end{array}$ & $\begin{array}{l}\text { Cumulative } \\
\text { Percent }\end{array}$ \\
\hline \multirow{6}{*}{ Valid } & Guidance and Counselling & 10 & 47.6 & 47.6 & 47.6 \\
\hline & Punishment & 6 & 28.6 & 28.6 & 76.2 \\
\hline & $\begin{array}{l}\text { Motivational Speakers } \\
\text { and Role models }\end{array}$ & 2 & 9.5 & 9.5 & 85.7 \\
\hline & Engaging Students & 2 & 9.5 & 9.5 & 95.2 \\
\hline & Involving Parents & 1 & 4.8 & 4.8 & 100 \\
\hline & Total & 21 & 100 & 100 & \\
\hline
\end{tabular}

From Table 4.9 above it can be observed that $10(47.6 \%)$ argue that guidance and counselling is the best method to be applied in enhancing discipline in school, $6(28.6 \%)$ are for punishment, $2(9.5 \%)$ say motivational speakers and role models to be applied, $2(9.5 \%)$ are contented with engaging students while $1(4.8 \%)$ posits that involving parents would be the best measure in enhancing discipline in school. From the discussion above it can be observed that guidance and counselling is recommended by the majority to be used by public boarding secondary schools in Nyanza province to curb unruly behavior among the students. The finding is in support of Wangai (2014) who posits that Guidance and counselling is the third force in education along with instruction, is an integral part of educational system. Guidance programmes for secondary school students are designed to address the physical, emotional, social, vocational and academic difficulties of adolescent students. This is to complement learning in the classroom and also enhance academic performance/achievements of students. Guidance plays a vital role in preventing educational, personal, social, mental emotional and other similar problems among secondary school students. In conclusion, the government should employ at least one counsellor in boarding public secondary schools to assist in controlling unruly students by counselling them.

Major challenges encountered in an effort to enhance discipline in school

On the discussion of major challenges encountered in an effort to enhance discipline in school, responses of the respondents were as shown in Table 4.10 below

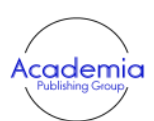

International Journal of Educational Studies

Vol. 3, No.2, pp. 73-87

2020

DOI: $10.53935 / 2641-533 x . v 3 i 2.143$

Funding: This study received no specific

financial support.

Article History:

Received: 13 April 2020

Revised: 23 June 2020

Accepted: 27 July 2020

Published: 21 August 2020

(C) 2020 by the authors; licensee Academic Publishing Group
Table-4.10. Major challenges encountered in an effort to enhance discipline in school

\begin{tabular}{|c|c|c|c|c|c|}
\hline \multicolumn{6}{|c|}{ Major challenges encountered in an effort to enhance discipline in school } \\
\hline & & Frequency & Percent & $\begin{array}{l}\text { Valid } \\
\text { Percent }\end{array}$ & $\begin{array}{l}\text { Cumulative } \\
\text { Percent }\end{array}$ \\
\hline \multirow{6}{*}{ Valid } & Lack of Parental Guidance & 10 & 47.6 & 47.6 & 47.6 \\
\hline & $\begin{array}{l}\text { Government Policies giving } \\
\text { students more rights against } \\
\text { those who administer them }\end{array}$ & 4 & 19 & 19 & 66.7 \\
\hline & Peer Pressure & 3 & 14.3 & 14.3 & 81 \\
\hline & Drop-out & 2 & 9.5 & 9.5 & 90.5 \\
\hline & $\begin{array}{l}\text { Inadequate Support from } \\
\text { some staff members }\end{array}$ & 2 & 9.5 & 9.5 & 100 \\
\hline & Total & 21 & 100 & 100 & \\
\hline
\end{tabular}


From Table 4.10 above it can be observed that $10(47.6 \%)$ agree that lack of parental guidance is the major challenge encountered in an effort to enhance discipline in school, 4 $(19.0 \%)$ say that government policy is giving students more rights against those who administer them, $3(14.3 \%)$ allude to peer pressure, $2(9.5 \%)$ say the school drop-out is accessioned by an attempt to enhance discipline in school, $2(9.5 \%)$ argue that there is inadequate support from some staff members. From the discussion above it can be observed that majority of the respondents say that lack of parental guidance is the Major challenge encountered in an effort to enhance discipline in school. Therefore parents should be involved in the discipline of their children. Jepkemei traced the deviant behavior manifested in schools to situations at home, saying many children report to school with deep-seated insecurities and frustrations. "Some parents are too busy to attend to the emotional needs of their children who then do as they please and keep bad company. On the other hand, parental over protection of children has created small monsters with strong entitlement tendencies," she argued. And when such children are admitted to schools that are as dysfunctional as their homes, it is a powder keg.

\subsection{Type of External Interference}

On the discussion of type of external interference with school, responses of the respondents were as shown in Table 4.11 below

Table-4.11. Type of external interference

\begin{tabular}{|c|c|c|c|c|c|}
\hline \multicolumn{6}{|c|}{ Type of external interference } \\
\hline & & Frequency & Percent & $\begin{array}{l}\text { Valid } \\
\text { Percent }\end{array}$ & $\begin{array}{l}\text { Cumulative } \\
\text { Percent }\end{array}$ \\
\hline \multirow{5}{*}{ Valid } & Parents & 4 & 19 & 33.3 & 33.3 \\
\hline & $\begin{array}{l}\text { Political and societal } \\
\text { interference }\end{array}$ & 6 & 28.6 & 50 & 83.3 \\
\hline & $\begin{array}{l}\text { Motorbike (Bodaboda) } \\
\text { operators }\end{array}$ & 1 & 4.8 & 8.3 & 91.7 \\
\hline & Uncooperative Workers & 1 & 4.8 & 8.3 & 100 \\
\hline & Total & 12 & 57.1 & 100 & \\
\hline Missing & System & 9 & 42.9 & & \\
\hline Total & & 21 & 100 & & \\
\hline
\end{tabular}

From Table 4.11 above it can be observed that 4 (19.0\%) say parents are interfering with school activity, $6(28.6 \%)$ point fingers at political class and the society, $1(4.8 \%)$ allude that motorbike (Bodaboda) operators are to blame for interfering with school activity while 1 (4.8\%) lay blame on uncooperative workers. From the discussion it can be observed that majority of the respondents posit that political and societal interference is causing students to be unruly and burn school buildings in boarding public secondary schools in Nyanza province. The finding is not in line with Polakoff (2014) who posited that both politicians and bureaucrats are viewed as critically important agents in the delivery of public projects. Politicians are elected by citizens to decide public policy, including the delivery of public projects, whereas bureaucrats are employed by the government to implement these policies. When faced by high levels of political competition in their constituencies, politicians may be incentivized to improve the quality of potentially votewinning public projects. Consequently, they may seek to overcome barriers such as bureaucrats' indecency, inertia, or corruption.

\section{Summary of Findings, Conclusions and Recommendations \\ 5.1. Introduction}

This chapter gives an overview of the study and is divided into four sections: the summary of the major findings, conclusions, recommendations, and suggestions for further studies. 


\subsection{Summary of the Major Findings}

The findings of the study are summarized as follows:

\subsection{Ways of Controlling Unruly Students so as to Curb Destruction of School Building in} Boarding Public Secondary Schools

This study was guided by the following question: What are the ways of controlling unruly students so as to curb destruction of school building in boarding public secondary schools in Nyanza?

The study established that 7 (33.3\%) support preventive type of discipline to be applied to curb indiscipline and unruly behavior in public secondary schools in Nyanza province, $3(14.3 \%)$ are for corrective measures while $10(47.6 \%)$ say that application of both preventive and corrective means of discipline are appropriate. Some respondents were in support of availability of counseling and guidance as a way to control unruly students as follows; 11 (52.4\%) agree that there is guidance and counseling staff in their school while $10(47.6 \%)$ say no, they do not have a guidance and counselor facility in their schools. $13(61.9 \%)$ say that staff cohesion in addressing indiscipline among students is firm, $2(9.5 \%)$ argue that is not very firm while $6(28.6 \%)$ pointed out that the staff cohesion in addressing indiscipline among students is fair. Other ways were discussed as $4(19.0 \%)$ say that meetings with prefects' body for consultations is as per need arises, 7 (33.3\%) argue that meetings with prefects' body is on weekly basis wile $10(47.6 \%)$ say it is monthly.

\subsection{Conclusions}

Ways of controlling unruly students so as to curb destruction of school building in boarding public secondary schools in Nyanza province were preventive type of discipline to be applied, corrective measures, and application of both preventive and corrective means of discipline. Other ways of controlling unruly students were guidance and counseling and meetings with prefects' body for consultations,

\section{Recommendations}

Based on the findings of the study which revealed that peer influence, occultism and poor parenting are some of the causes of indiscipline among students in public boarding secondary schools in Nyanza province, the researcher makes the following recommendations:

i. The Ministry of Education, Science and Technology should ensure efficient and timely supervision of teachers to improve teachers' class attendance and syllabus completion.

Ways of controlling unruly students should be identified by stake holders and/or ministry of education should put stern measures for the students who resort to burning of school property to seek redress.

\section{References}

Best, \& Khan. (2006). Research methods in education. London: Routledge Falmer.

Cohen, L., Marion, L., \& Morrison, K. (2017). Research methods in education. London: Routledge Falmer.

Docking, G. R. (1987). Work redesign. Reading: M. A. Addison- Wesle.

Duke, L. (1989). Evaluation, management and performance indicators. In J. Elliot (2ed). Reconstructing teacher education. London: Falmer Press.

Dunham, O. J. (2016). Effects of work-related attitudes on the intention to leave the profession: An examination of the school teachers in Nigeria. Journal for Educational Administration and Leadership, 33(3), 355-369.

International Journal of Educational F. E., \& Garcia, J. E. (201
performance. New York.

Fiedler, F. E., \& Garcia, J. E. (2017). New approaches to effective leadership: Cognitive resources and organizational

Gall, J. P., Meredith, D. G., \& Walter, R. B. (2013). Educational research: An introduction (7th ed.). Allya and Bacon.

Graffin, I. N. (1996). Factors determining commitment and non-commitment to teaching among primary school teachers in three districts. Keiyo-Markwet and Nyeri.

Jones, N. (2009). Daily newspaper. School management and pupils behavior. London: Falmer Press.

Kerlinger, F. N. (2013). Foundation of behavioral research (2nd ed.). New York: HoltRinehart and Winston Inc.

Kothari, C. K. (2004). Research methodology; methods and practices. New York: Oxford University Press.

Kuonin, P. S. (1970). Management: Challenges in the (21st ed.). New York: West Publishing Company.

Mbithi, L. R. (2012). Foundation of school administration Nairobi. Micheni: Oxford University Press. 
Mbiti, D. M. (2014). Foundation of school administration nairobi. Micheni: Oxford University Press.

Montgomery, L. (1966). Work and the nature of man. N. Y: World Publishin.

Mwangi, D. D. (2018). Educational administration: Planning and supervision. Ben City: Jodah Publications.

Okumbe. (2001). Human resource management. An education perspective. Nairobi: Kenya Education Development and Research Bureau.

Okumbe. (2008). Educational management: Theory and practice: Nairobi University Press.

Orodho, J. A. (2004). Teaching of writing research proposals and reports in education and social science (1st ed.). Nairobi: Mosala Publishers.

Ovell, S. (2007). Discipline in schools online resource from Nalanda Institute. Retrieved from http://www.nalandainstitute.org/aspfiles/discipline.asp

Polakoff, L. P. (2014). Work and health. Washington DC: Press Associates Inc.

Reid, S. (1986). A discussion of the link between the pre-school curriculum and the 8.4.4. Standard one curriculum in Kenya. Mombasa, Kenya: Madrassa Resource Center.

Said, S. (2016). A discussion of the link between the pre-school curriculum and the 8.4.4.standard one curriculum in Kenya. Mombasa, Kenya: Madrassa Resource Center.

Tattum, D. (2009). Disruptive pupil management. London.

Thorndike, J. R. (1911). Development of the job diagnostic survey. Journal of Applied Psychology, 60(2), 159-162.

Trophim, B. W. (2016). Conducting education research. London: Collier-Macmillan.

Wangai, N. (2014). Review literature on adolescents, youth sexual and reproductive health. Nairobi.

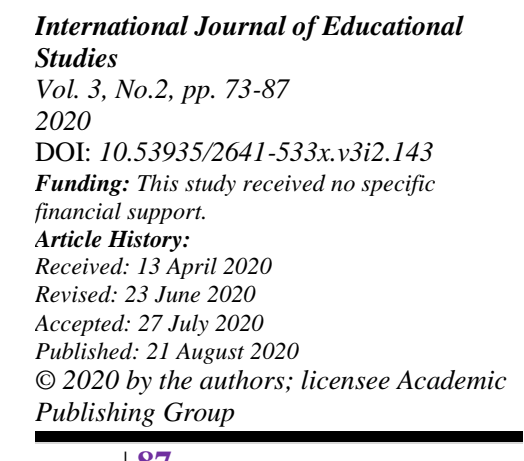

